\title{
Feeding behavior of dairy cows fed different levels of castor meal in the diet
}

\author{
Comportamento ingestivo de vacas leiteiras alimentadas com \\ diferentes níveis de farelo de mamona na dieta
}

\author{
Dicastro Dias de Souza ${ }^{1 *}$; Fabiano Ferreira da Silva ${ }^{2}$; Alex Resende Schio ${ }^{3}$; \\ Antonio Ferraz Porto Junior ${ }^{1}$; Robério Rodrigues Silva ${ }^{2}$; \\ Bismarck Moreira Santiago ${ }^{4}$; Eli Santana de Oliveira Rodrigues ${ }^{3}$; \\ Andrey Couto Abreu ${ }^{4}$; Camile Carvalho Pacheco ${ }^{4}$ J Jemima Fialho Muricy ${ }^{4}$
}

\begin{abstract}
This study aimed to evaluate the inclusion of castor meal in the diet of lactating cows in grazing system and its implications in feeding behavior. Eight Holstein x Zebu crossbred cows, with average milk production adjusted to 300 days in the previous lactation, between 5000 and $6000 \mathrm{~kg}$ and $100.33 \pm 13.33$ days of lactation and average body weight of $509.47 \pm 61.90 \mathrm{~kg}$, were distributed in two $4 \mathrm{x} 4$ Latin squares, with 4 levels of castor meal inclusion in the total diet, and using Brachiaria brizantha pasture as roughage. The experiment consisted of four experimental periods, lasting 21 days each. In each trial, the roughage and supplements were collected for evaluation of chemical composition. Animals were subjected to visual observation for evaluation of feeding behavior for 24 hours, from the $20^{\text {th }}$ to the $21^{\text {st }}$ day of each experimental period. The observations of the activities were recorded every five minutes. We determined the number of ruminating chews and the time spent in rumination of each ruminal bolus with the use of digital stopwatch. There was a quadratic effect for the grazing time with maximum point of inclusion of castor meal at $4.61 \%$ in the diet; other variables did not differ: rumination, idleness, trough, rumination efficiency, feeding and grazing time, rumination and idleness. Castor meal can be included in the diet with levels up to $10 \%$, for little changes in the feeding behavior of animals.
\end{abstract}

Key words: Brachiaria brizantha. Grazing. Rumination. Feed efficiency.

\section{Resumo}

Objetivou-se avaliar a inclusão de farelo de mamona na dieta de vacas lactantes em sistema de pastejo e suas implicações no comportamento ingestivo. Foram utilizadas 8 vacas mestiças Holandês x Zebu, com produção média de leite ajustado para 300 dias na lactação anterior, entre 5.000 e $6.000 \mathrm{~kg}$ e $100,33 \pm 13,33$ dias de lactação e peso corporal médio de 509,47 $\pm 61,90$. As 8 vacas foram distribuídas em dois Quadrados Latinos 4 x 4, com 4 níveis de inclusão de farelo de mamona na dieta total e o volumoso utilizado foi pasto de Brachiaria brizantha. O experimento foi constituído de quatro períodos

\footnotetext{
${ }^{1}$ Discentes do Curso de Doutorado do Programa de Pós-Graduação em Zootecnia, Universidade Estadual do Sudoeste da Bahia, UESB, Itapetinga, BA, Brasil. E-mail: dico111_3@hotmail.com; ferrazporto@hotmail.com

2 Profs. Pleno, Departamento de Tecnologia Rural e Animal, UESB, Itapetinga, BA, Brasil. E-mail: ffsilva@pq.cnpq.br; rrsilva. uesb@hotmail.com

3 Discentes de Pós-Doutorado Drs., Programa de Pós-Graduação em Zootecnia, UESB, Itapetinga, BA, Brasil. E-mail: resendezoo@ hotmail.com; eli.uesb@hotmail.com

${ }^{4}$ Discentes do Curso de Graduação em Zootecnia, UESB, Itapetinga, BA, Brasil. E-mail: bismarck.santiago@hotmail.com; andrey_couto_13@hotmail.com; kmilipc@hotmail.com; jemimamuricy@hotmail.com

* Author for correspondence
} 
experimentais, com duração de 21 dias cada. Em cada período experimental, foi realizada coleta do volumoso e dos suplementos para avaliação de sua composição químico-bromatológica. Os animais foram submetidos a períodos de observação visual para avaliação do comportamento ingestivo, durante 24 horas, que ocorreram do $20^{\circ}$ para o $21^{\circ}$ dia de cada período experimental. As observações das atividades foram registradas a cada cinco minutos de intervalo. Foi realizada a determinação do número de mastigações merícicas e do tempo despendido na ruminação de cada bolo ruminal com a utilização de cronômetro digital. Houve efeito quadrático para o tempo de pastejo com ponto de máxima inclusão de farelo de mamona em 4,61\% na dieta, as outras variáveis estudadas não diferiram: tempo de ruminação, ócio, cocho, eficiência de ruminação, alimentação e período de pastejo, ruminação e ocio. Pode-se incluir a torta de mamona em até $10 \%$.

Palavras-chave: Brachiaria brizantha. Pastejo. Ruminação. Eficiência alimentar.

\section{Introduction}

Castor bean (Ricinus communis L.), originated in Ethiopia, is an oleaginous plant belonging to the family of Euphorbiaceae, which, in Brazil, is used for the extraction of oil and production of biodiesel. Domestic production of castor is concentrated in the Northeastern region, with 154,018 tons of castor beans for an area of 227,068 ha, which corresponds to $91.24 \%$ and $93.80 \%$, respectively, of production and planted area across the country; the State of Bahia is the main producer, with $78.39 \%$ of national production (IBGE, 2007).

Castor meal is a byproduct from biodiesel production with potential use in ruminant nutrition. However, this potential is little explored by the presence of ricin, a toxic protein present in the seed, part of the family of enzymes known as Ribosome Inhibiting Proteins (RIP), which are capable of inactivating ribosomes, breaking the bond between adenine and ribose, thus impeding protein synthesis, leading to cell death and consequently the death of the animal (AZEVEDO; LIMA, 2001).

According to Costa et al. (2011), analysis of feeding behavior is an important tool in the evaluation of diets and management of animals to obtain superior productive performance. In this sense, a way of assessing the quality of a byproduct is to assess the feeding behavior, because when the animal is subjected to any negative effect, caused by diet, management, health or climatic stress, it has a direct influence on its feeding behavior.
Daily activities of ruminants are divided into three basic behaviors: feeding, ruminating and idle; the time spent in feeding is alternated with periods of rumination or idleness (PAZDIORA et al., 2011).

Ruminants, like other species, try to keep the intake of feed according to their nutritional requirements and adjust the feeding behavior in response to changes in the environment (HODGSON, 1985).

In this context, this study aimed to evaluate the inclusion of castor meal in the diet of lactating cows in grazing system and its implications in feeding behavior.

\section{Material and Methods}

The experiment was conducted at the Farm Valeu Boi, municipality of Encruzilhada, State of Bahia, with eight Holstein x Zebu crossbred cows (degree of blood ranging from $1 / 2$ to $3 / 4 \mathrm{H}$ $\mathrm{x} Z$ ), in the third to fifth lactation order, with average milk production adjusted to 300 days in the previous lactation, between 5000 and $6000 \mathrm{~kg}$ and average body weight of $509.47 \pm 61.90 \mathrm{~kg}$. Animals were also selected by days of lactation, at $100.33 \pm 13.33$ days in the beginning of the experimental period. Cows were distributed in two 4 x 4 Latin squares, with 4 levels of castor meal inclusion in the diet (Table 1). The diets consisted of concentrate and using Brachiaria 
brizantha pasture as roughage, in intermittent grazing system with one day of occupation in length and 29-day rest period, and stocking rate of $1.0 \mathrm{UA} / \mathrm{ha}$.
Castor meal was treated before the start of the experiment with calcium oxide according to Oliveira (2008), which consists of the treatment $1000 \mathrm{~g}$ meal with $60 \mathrm{~g}$ calcium hydroxide $\left(\mathrm{Ca}(\mathrm{OH})_{2}\right)$ at $60^{\circ} \mathrm{C}$ for 8 hours.

Table 1. Ingredients of concentrates, on a dry matter basis, and forage: concentrate ratio for lactating cows fed different levels of castor meal.

\begin{tabular}{lcccc}
\hline \multirow{2}{*}{ Ingredient \% } & \multicolumn{3}{c}{ Treatment } \\
\cline { 2 - 5 } & $0.00 \%$ & $3.33 \%$ & $6.66 \%$ & $10.00 \%$ \\
\hline Ground corn & 55.52 & 53.80 & 52.11 & 50.46 \\
Whole cottonseed & 23.68 & 23.37 & 23.10 & 22.81 \\
Soybean meal & 16.34 & 10.92 & 5.62 & 0.44 \\
Castor meal & 0.00 & 7.60 & 15.01 & 22.27 \\
Urea & 1.34 & 1.32 & 1.31 & 1.29 \\
Limestone & 1.25 & 1.15 & 1.03 & 0.93 \\
Mineral salt ${ }^{(1)}$ & 1.87 & 1.85 & 1.82 & 1.80 \\
\hline & \multicolumn{4}{c}{43.59} \\
\hline Forage & 43.26 & Ratio \% & 44.70 & 56.52 \\
Concentrate & 56.74 & 55.30 & 55.48 & 56.41 \\
\hline
\end{tabular}

${ }^{(1)}$ Composition: Calcium 200 g; Cobalt 200 mg; Copper 1,650 mg; Sulfur 12 g; Iron 560 mg; Fluorine (max) 1,000g; Phosphorus 100g; Iodine 195 mg; Magnesium 15 mg; Manganese 1,960 mg; Nickel 40 mg; Selenium 32 mg; Sodium 68 g; Zinc 6,285 mg.

The composition of the concentrate (Table 1) was defined by balancing the diet to contain sufficient nutrients for maintenance, body weight gain of $0.15 \mathrm{~kg}^{-1} \mathrm{day}^{-1}$ and production of $25 \mathrm{~kg}$ milk day ${ }^{-1}$, according to NRC (2001), based on data of the chemical composition of the pasture Brachiaria brizantha, corn, soybean meal, cotton seed and castor meal, held a week before the trial period.
For concentrate intake, animals were housed in individual pens of $16 \mathrm{~m}^{2}$, roofed, equipped with individual plastic troughs. The concentrate was supplied twice daily at 08:00 after milking and 17:00 before milking. The trial began on February $11^{\text {st }}, 2014$, consisting of four experimental periods, lasting 21 days each, with the first 15 days for adaptation and the other six days for data collection. In each trial, roughage and supplements were collected to evaluate their chemical composition (Table 2). 
Table 2. Chemical composition of Brachiaria brizantha, castor meal and concentrates.

\begin{tabular}{lcccccc}
\hline \multirow{2}{*}{ Nutrients } & \multirow{2}{*}{ Castor meal } & \multirow{2}{*}{ Brachiaria brizanta $^{1}$} & \multicolumn{5}{c}{ Treatments } \\
\cline { 4 - 6 } & & & $0.00 \%$ & $3.33 \%$ & $6.66 \%$ & $10.00 \%$ \\
\hline $\mathrm{DM}^{(2)}$ & 88.98 & 25.68 & 88.09 & 87.97 & 87.56 & 88.02 \\
$\mathrm{OM}^{(3)}$ & 70.90 & 92.89 & 92.01 & 91.35 & 90.68 & 90.01 \\
$\mathrm{CP}^{(4)}$ & 32.39 & 8.23 & 20.68 & 20.81 & 21.15 & 19.98 \\
$\mathrm{EE}^{(5)}$ & 3.30 & 5.65 & 7.50 & 7.09 & 7.62 & 7.74 \\
$\mathrm{NFC}^{(6)}$ & 4.73 & 11.18 & 46.51 & 48.83 & 44.98 & 39.58 \\
$\mathrm{NDFap}^{(7)}$ & 30.48 & 67.82 & 17.32 & 14.61 & 16.92 & 22.81 \\
$\mathrm{ADF}^{(8)}$ & 43.81 & 54.99 & 16.05 & 16.49 & 17.64 & 15.33 \\
$\mathrm{MM}^{(9)}$ & 29.09 & 7.11 & 7.98 & 8.65 & 9.33 & 9.91 \\
\hline
\end{tabular}

${ }^{(1)}$ Simulated grazing; ${ }^{(2)} \mathrm{DM}$ - Dry matter; ${ }^{(3)} \mathrm{OM}$ - Organic matter; ${ }^{(4)} \mathrm{CP}$ - Crude Protein; ${ }^{(5)} \mathrm{EE}$ - Ether extract; ${ }^{(6)} \mathrm{NFC}$ - Non-fiber carbohydrate; ${ }^{(7)}$ NDFap -Neutral detergent fiber corrected for ash and protein, ${ }^{(8)} \mathrm{ADF}$-Acid detergent fiber and ${ }^{(9)} \mathrm{MM}-\mathrm{Mineral}$ Matter.

Roughage mass was estimated with the aid of a square of known area $\left(0,25 \mathrm{~m}^{2}\right)$, which was randomly thrown 40 times per paddock, and only in 12 , roughage was cut and weighed on a digital scale accurate to 5 grams. After homogenizing, the collected forage formed a composite sample for the separation of leaf blade, stem and dead material. The amount of forage biomass available per paddock was calculated an expressed as kg DM ha1. Data on forage availability and allowance during the experiment are presented in Table 3. During the trial period, the environmental temperature (Table 4) was recorded on the farm.

Table 3. Availability and allowance of forage relative to the experimental periods.

\begin{tabular}{lccccc}
\hline & \multicolumn{5}{c}{ Experimental periods } \\
\cline { 2 - 5 } & 1 & 2 & 3 & 4 & Mean \\
\hline Forage mass kg ha-1 & 2421.23 & 3419.50 & 1182.32 & 1226.94 & 2062.50 \\
OF $^{(1)} \mathrm{kg} \mathrm{DM} \mathrm{100} \mathrm{kg} \mathrm{PV}^{-1}$ & 7.68 & 10.81 & 3.74 & 3.88 & 6.53 \\
Leaf \% & 35.60 & 19.43 & 30.35 & 25.33 & 27.67 \\
Stem \% & 42.41 & 65.40 & 44.64 & 44.80 & 49.31 \\
Dead material \% & 22.59 & 15.16 & 25 & 29.87 & 23.15 \\
Leaf: stem & 0.84 & 0.29 & 0.68 & 0.56 & 0.59 \\
\hline
\end{tabular}

${ }^{1}$ Forage allowance.

Table 4. Monthly average, minimum and maximum temperatures during the study period.

\begin{tabular}{lcccc}
\hline \multirow{2}{*}{ Variable } & \multicolumn{3}{c}{ Months } \\
\cline { 2 - 5 } & February & March & April & May \\
\hline Maximum temperature $\left({ }^{\circ} \mathrm{C}\right)$ & 30.24 & 30.10 & 27.87 & 21.9 \\
Minimum temperature $\left({ }^{\circ} \mathrm{C}\right)$ & 23.72 & 23.44 & 22.12 & 19.93 \\
Average temperature $\left({ }^{\circ} \mathrm{C}\right)$ & 26.97 & 26.78 & 24.95 & 20.92 \\
\hline
\end{tabular}


Animals were visually observed for evaluation of feeding behavior for 24 hours, from the day 20 to the day 21 of each trial period. The observations of the activities were recorded at five-minute intervals, as recommended by Mezzarila et al. (2011).

The number of ruminating chews and time spent in rumination of each bolus was measured using a digital stopwatch. For this evaluation, all animals of the experiment were observed, considering three ruminal bolus, at three different times of the day. During the night, observers used flashlights to make the observations.

The number of ruminal bolus per day (RBD), the total chewing time per day (CTD) and the number of chews per day (NCD) were determined according to Bürger et al. (2000).

The voluntary intake of DM and NDFap was used to evaluate feeding and rumination efficiencies relative to the amount in grams of DM and NDF per unit time and per feeding period. The number of ruminal bolus per day was obtained by dividing the total rumination time (minutes) by the average time spent in ruminating a bolus.

Feeding and rumination efficiencies were calculated as follows:

$$
\begin{aligned}
& \mathrm{FE}=\text { IDM. FD- }{ }^{1} \\
& \text { FENDFap }=\text { INDFap FD- }{ }^{1} \\
& \text { RE }=\text { IDM RT- }{ }^{1} \\
& \text { RENDFap }=\text { INDFAP RT }{ }^{1}
\end{aligned}
$$

Where: $\mathrm{FE}=$ feeding efficiency; IDM = daily dry matter intake (grams DM); FD = feeding time (hours); FENDFap = feeding efficiency of NDFap; INDFap = daily intake of NDFap (grams NDFap); RT = rumination time (hours); RENDFc = rumination efficiency (grams NDFap).

The number of ruminal bolus per day was obtained as follows: total rumination time (min) divided by the average time spent in ruminating a bolus. The concentration of DM and NDF in each bolus ( $\mathrm{g}$ ) was multiplied by the number of bolus ruminated daily (SILVA et al., 2006).
The number of periods of feeding, rumination and idleness were quantified by the number of sequences of activities observed in the spreadsheet. The average daily duration of these periods of activity was calculated by dividing the total duration of each activity of feeding, rumination and idleness by their respective number of discrete periods (SILVA et al., 2006).

Data were evaluated by analysis of variance and regression analysis. The statistical models were selected according to the significance of the regression coefficients using the F-test at 5\% probability and coefficient of determination $\left(\mathrm{R}^{2}\right)$.

\section{Results and Discussion}

For the variable grazing time, there was a quadratic effect with maximum point of inclusion at $4.61 \%$ castor meal, and the value found herein for the maximum grazing time was 700 minutes, within the range reported by Euclides et al. (2000), which claims that, in general, grazing time varies from 420 to 720 minutes a day and very close to that registered by Zanine et al. (2007), who also worked with Brachiaria brizantha and verified an average of 649.2 grazing minutes per day. Variations in the grazing time can be attributed to the passage rate of the feed through the rumen and the consumption/ demand ratio (CARVALHO, 1997).

Changes in times of grazing, rumination, trough and idleness can be influenced by the level of forage or concentrate (MACARI et al., 2007; BREMM et al., 2008), forage canopy structure (REGO et al., 2006; PALHANO et al., 2007; ÍTAVO et al., 2008; BAGGIO et al., 2009; ZANINE et al., 2009; TEIXEIRA et al., 2010, 2011), neutral detergent fiber content in the diet and its effectiveness (SANTOS et al., 2006), the production, time and number of milkings (BALOCCHI et al., 2002). In the present study, there was little variation in the aforementioned factors, highlighting the lack of difference for time of rumination, idle and trough (Table 5). 
Table 5. Time spent in grazing, ruminating and idle, in minutes of lactating cows fed different levels of castor meal in the diet.

\begin{tabular}{lccccccc}
\hline \multirow{2}{*}{ Activity } & \multicolumn{9}{c}{ Treatment } & \multirow{2}{*}{$\hat{\mathrm{Y}}^{(1)}$} & \multirow{2}{*}{$\mathrm{CV} \%{ }^{(2)}$} & \multirow{2}{*}{$\mathrm{P}^{(3)}$} \\
\cline { 2 - 5 } & $0.00 \%$ & $3.33 \%$ & $6.66 \%$ & $10.00 \%$ & & & \\
\hline Grazing & 622.50 & 681.88 & 670.63 & 605.63 & $(*)$ & 9.01 & 0.048 \\
Ruminating & 340.62 & 318.74 & 331.25 & 339.38 & 332.50 & 19.95 & 0.906 \\
Idle & 432.50 & 397.50 & 400.62 & 453.75 & 421.10 & 12.84 & 0.153 \\
Trough & 44.38 & 41.88 & 37.50 & 40.63 & 41.10 & 19.09 & 0.389 \\
\hline
\end{tabular}

${ }^{(1)}$ Regression equations; ${ }^{(2)}$ Coefficient of variation, in percentage; ${ }^{(3)}$ Probability of error; ${ }^{(*)} \mathrm{y}=-2.679 \mathrm{x}^{2}+24.704 \mathrm{x}+624.93$; $\mathrm{R}^{2}=$ 0.997 .

Santana Júnior et al. (2013) argue that the time used for grazing in the trough is directly related to the amount of supplement given, and evidenced no difference for time in the trough, because the amount of supplement furnished was very similar between the treatments and the time of delivery, which was the same for all animals.

In relation to the amount of NDFap ingested by treatment, it was equal and caused no difference in rumination, as rumination time is directly proportional to NDF content and physical form of the diet (VAN SOEST, 1994).

There was no effect of castor meal on the dry matter intake, thus, intake of neutral detergent fiber and total digestible nutrients were not affected (Table 6).

The lack of difference for intake of DM, NDF and TDN and time spent in rumination also caused a lack of difference in FE and RE, in relation to both DM and NDF (Table 6). The intake efficiency of DM and NDF and rumination efficiency of DM and NDF are influenced by the type of forage (PINTO et al., 2010). Diets in this experiment contained the same source of forage, as the exclusive source, varying only the levels of castor meal. Nevertheless, no changes were detected in the grazing efficiency of DM and NDFap possibly due to the lack of difference in NDFap intake of diets.

Table 6. Parameters of grazing efficiency and ruminating chews of lactating cows fed different levels of castor meal.

\begin{tabular}{lccccccc}
\hline & \multicolumn{9}{c}{ Treatment } & \multirow{2}{*}{$\hat{\mathrm{Y}}^{(1)}$} & \multirow{2}{*}{$\mathrm{CV} \%$} & \multirow{2}{*}{$\mathrm{P}^{(3)}$} \\
\cline { 2 - 5 } & $0.00 \%$ & $3.33 \%$ & $6.66 \%$ & $10.00 \%$ & & & \\
\cline { 2 - 6 } $\mathrm{DMI}^{(4)}\left(\mathrm{kg} \mathrm{day}^{-1}\right)$ & 12.98 & 13.44 & 13.69 & 13.48 & 13.4 & 7.45 & 0.544 \\
$\mathrm{INDF}^{(5)}\left(\mathrm{kg} \mathrm{day}^{-1}\right)$ & 1.98 & 2.03 & 2.08 & 1.99 & 2.02 & 4.00 & 0.08 \\
$\mathrm{ITDN}^{(6)}\left(\mathrm{kg} \mathrm{day}^{-1}\right)$ & 8.25 & 8.66 & 8.89 & 8.35 & 8.28 & 10.03 & 0.330 \\
$\mathrm{FE}^{(7)}\left(\mathrm{g} \mathrm{DM} \mathrm{h}^{-1}\right)$ & 1322.17 & 1297.37 & 1259.66 & 1267.97 & 1286.8 & 19.11 & 0.955 \\
$\mathrm{FENDF}^{(8)}\left(\mathrm{gNDF} \mathrm{h}^{-1}\right)$ & 496.43 & 473.91 & 499.52 & 551.96 & 505.45 & 18.25 & 0.403 \\
$\mathrm{FETDN}^{(9)}\left(\mathrm{gTDN} \mathrm{h}^{-1}\right)$ & 839.64 & 807.72 & 816.30 & 879.09 & 835.69 & 14.10 & 0.637 \\
$\mathrm{RE}^{(10)}\left(\mathrm{g} \mathrm{DM} \mathrm{h}^{-1}\right)$ & 2628.85 & 3157.57 & 2855.85 & 2461.25 & 2775.8 & 25.98 & 0.279 \\
$\operatorname{RENDF}^{(11)}\left(\mathrm{gNDF} \mathrm{h}^{-1}\right)$ & 939.17 & 1056.76 & 1062.41 & 1000.95 & 1014.8 & 19.97 & 0.593 \\
$\operatorname{RETDN}^{(12)}\left(\mathrm{gTDN} \mathrm{h}^{-1}\right)$ & 1589.63 & 1802.99 & 1762.93 & 1606.57 & 1690.5 & 20.91 & 0.532 \\
\hline
\end{tabular}

${ }^{1}$ Regression equations, ${ }^{2}$ Coefficient of variation, in percentage, ${ }^{3}$ Probability of error, 4DMI - dry matter intake; ${ }^{5}$ INDFap - intake of neutral detergent fiber corrected for ash and protein; ${ }^{6}$ ITDN - intake of total digestible nutrients; ${ }^{7} \mathrm{FE}$ - grazing efficiency of dry matter; ${ }^{8} \mathrm{FENDFap}$ - grazing efficiency of neutral detergent fiber corrected for ash and protein; ${ }^{9} \mathrm{FETDN}$ - grazing efficiency of total digestible nutrients; ${ }^{10} \mathrm{ER}$ - rumination efficiency of dry matter; ${ }^{11} \mathrm{RENDFap}$ - rumination efficiency of neutral detergent fiber corrected for ash and protein; ${ }^{12} \mathrm{RETDN}$ - rumination efficiency of total digestible nutrients. 
The inclusion of castor meal in the diet had no influence on the number of periods of grazing (NPG), rumination (NPR), idleness (NPI), on the time spent per period of grazing (TPG), ruminating (TPR), idleness (TPI) and in the trough (TPT), whose values can be found in Table 7 .

Table 7. Number of periods and duration of behavioral activities of lactating cows fed different levels of castor meal.

\begin{tabular}{cccccccc}
\hline \multirow{2}{*}{ Behavioral activities } & \multicolumn{5}{c}{ Levels of castor meal } & \multirow{2}{*}{$\hat{\mathrm{Y}}^{(1)}$} & \multirow{2}{*}{$\mathrm{CV} \%$} \\
\cline { 2 - 5 } & $0.00 \%$ & $3.33 \%$ & $6.66 \%$ & $10.00 \%$ & \multirow{2}{*}{$\mathrm{P}^{(3)}$} \\
\hline $\mathrm{NPG}^{4}$ & 5.37 & 5.25 & 5.12 & 5.25 & 5.25 & 19.05 & 0.968 \\
$\mathrm{NPR}^{5}$ & 9.75 & 9.25 & 9.37 & 9.12 & 9.37 & 20.07 & 0.918 \\
$\mathrm{NPI}^{6}$ & 10.75 & 10.62 & 10.00 & 10.37 & 10.43 & 17.38 & 0.849 \\
$\mathrm{TSP}^{7}$ & 1.99 & 2.29 & 2.25 & 1.98 & 2.13 & 23.83 & 0.491 \\
$\mathrm{TSR}^{8}$ & 0.59 & 0.57 & 0.69 & 0.64 & 0.62 & 36.09 & 0.697 \\
$\mathrm{TSI}^{9}$ & 0.67 & 0.63 & 0.67 & 0.79 & 0.69 & 25.99 & 0.365 \\
$\mathrm{TST}^{10}$ & 0.37 & 0.35 & 0.31 & 0.34 & 0.34 & 19.10 & 0.390 \\
\hline
\end{tabular}

${ }^{1}$ Regression equations, ${ }^{2}$ Coefficient of variation, in percentage, ${ }^{3}$ Probability of error; ${ }^{4}$ Number of periods grazing; ${ }^{5}$ Number of periods ruminating; ${ }^{6}$ Number of periods in idle; ${ }^{7}$ Time spent in grazing; ${ }^{8}$ Time spent in ruminating; ${ }^{9}$ Time spent in idle; ${ }^{10}$ Time spent in the trough.

Probably, because of the grazing habit of cattle, according to Mezzalira et al. (2011), the number of meals and the time spent in meals are directly related, which indicates that the difference in the time spent in grazing or ruminating, the number of periods and the time spent per period in these activities can present similarities, when diets are homogeneous and the concentrate is offered at the same time every day. Furthermore, cattle exhibit collective behavior.

Dado and Allen (1995), however, emphasize the proportionality in the number of rumination periods with the dietary fiber content, reflecting the need to process the rumen digestion, maximizing the digestive efficiency.

\section{Conclusion}

Castor meal can be included in the diet with levels of up to $10 \%$ for little changes in the grazing behavior of animals.

\section{References}

AZEVEDO, D. M. P. de; LIMA, E. F. (Ed.). $O$ Agronegócio da mamona no Brasil. Campina Grande: Embrapa Algodão, 2001. 350 p.

BAGGIO, C.; CARVALHO, P. C. F.; SILVA, J. L. S.; ANGHINONI, I.; LOPES, M. L. T.; THUROWET, J. M. Padrões de deslocamento e captura de forragem por novilhos em pastagem de azevém-anual e aveia-preta manejada sob diferentes alturas em sistema de integração lavoura-pecuária. Revista Brasileira de Zootecnia, Viçosa, MG, v. 38, n. 2, p. 215-222, 2009.

BALOCCHI, O.; PULIDO, R.; FÉRNANDEZ, J. Comportamiento de vacas lecheras en pastoreo com y sin suplementación com concentrado. Agricultura Técnica, v. 62 , n. 1, p. 87-98, 2002.

BREMM, C.; SILVA, J. H. S.; ROCHA, M. G.; ELEJALDE, D. A. G.; OLIVEIRA NETO, R. A.; CONFORTIN, A. C. C. Comportamento ingestivo de ovelhas e cordeiras em pastagem de azevém-anual sob níveis crescentes de suplementação. Revista Brasileira de Zootecnia, Viçosa, MG, v. 37, n. 12, p. 2097-2106, 2008.

BÜRGER, P. J.; PEREIRA, J. C.; QUEIROZ, A. C.; SILVA, J. F. C.; VALADARES FILHO, S. C.; CECON, P. R.; CASALI, A. D. P. Comportamento ingestivo em bezerros holandeses alimentados com dietas contendo diferentes níveis de concentrado. Revista Brasileira de Zootecnia, Viçosa, MG, v. 29, n. 1, p. 236-242, 2000. 
CARVALHO, P. C. F. A estrutura da pastagem e o comportamento ingestivo de ruminantes em pastejo. In: SIMPÓSIO SOBRE AVALIAÇÃO DE PASTAGENS COM ANIMAIS, 2., 1997, Maringá. Anais... Maringá: Universidade Estadual de Maringá, 1997. p. 25-52.

COSTA, L. T.; SILVA, F. F.; VELOSO, C. M.; PIRES, A. J. V.; ROCHA NETO, A. L.; BONOMO, P.; MENDES, F. B. L.; OLIVEIRA, J. S.; AZEVÊDO, S. T.; SILVA, V. L. Comportamento ingestivo de vacas alimentadas com cana-de-açúcar e diferentes níveis de concentrado. Archivos de Zootecnia, Córdoba, v. 60, n. 230, p. 265273, 2011.

DADO, T. G.; ALLEN, M. S. Intake limitations feeding behavior and rumen function of cows challen ged wuth rumen fill from dietary fiber on inrt bulk. Journal of Dairy Science, Champaign, v. 78, n. 3, p. 118-133, 1995.

EUCLIDES, V. P. B.; CARDOSO, E. G.; MACEDO, M. C. M.; OLIVEIRA, M. P. Consumo voluntário de Brachiaria decumbens cv. Basilisk e Brachiaria brizantha cv. Marandu sob pastejo. Revista Brasileira de Zootecnia, Viçosa, MG, v. 29, n. 6, p. 2200-2208, 2000 .

HODGSON, J. Grazing management science into practice. Essex: Lougman Group UK Ltda., 1985. 203 p.

INSTITUTO BRASILEIRO DE GEOGRAFIA E ESTATÍSTICA - IBGE. Sistema IBGE de recuperação automática - SIDRA. Brasília: IBGE, 2007. Disponível em: $\quad<$ http://www.sidraibge.gov.br/bda/Table/listabl. asp?c=1612\&z=p\&o=20>. Acesso em: 10 jul. 2015 .

ÍTAVO, L. C. V.; SOUZA, S. R. M. B. O.; RÍMOLI, J.; ÍTAVO, C. C. B. F.; DIAS, A. M. Comportamento ingestivo diurno de bovinos em pastejo contínuo e rotacionado. Archivos de Zootecnia, Córdoba, v. 57, n. 217, p. 43-52, 2008.

MACARI, S.; ROCHA, M. G.; PÖTTER, L.; ROMAN, J.; BREMM, C.; COSTA, V. G. Comportamento ingestivo diurno de novilhas de corte recebendo níveis de suplemento. Ciência Rural, Santa Maria, v. 37, n. 6, p. 1746-1752, 2007.

MEZZALIRA, J. C.; CARVALHO, P. C. F.; FONSECA, L.; BREMM, C.; REFFATTI, M. V.; POLI, C. H. E. C.; TRINDADE, J. K. Aspectos metodológicos do comportamento ingestivo de bovinos em pastejo. Revista Brasileira de Zootecnia, Viçosa, MG, v. 40, n. 5, p. 11141120, 2011.

NATIONAL RESEARCH COUNCIL - NRC. Nutrient requeriments of dairy cattle. $7^{\text {th }}$ rev. ed. Washington, D.C.: National Academies Press, NAP, 2001. 381 p.
OLIVEIRA, A. S. Co-produto da extração de óleo de sementes de mamona e de girassol na alimentação de ruminantes. 2008. Tese (Doutorado em Zootecnia) Universidade Federal de Viçosa, Viçosa, MG.

PALHANO, A. L.; CARVALHO, P. C. F.; DITTRICH, J. R.; MORAES, A.; SILVA, S. C.; MONTEIRO, A. L. G. Características do processo de ingestão de forragem por novilhas holandesas em pastagens de capim-mombaça. Revista Brasileira de Zootecnia, Viçosa, MG, v. 36, n. 4, p. 1014-1021, 2007.

PAZDIORA, R. D.; BRONDAN, I. L.; SILVEIRA, M. F.; ARBOITTE, M. Z.; CATTELAM, J.; PAULA, P.

C. Efeitos da frequência de fornecimento do volumoso e concentrado no comportamento ingestivo de vacas e novilhas em confinamento. Revista Brasileira de Zootecnia, Viçosa, MG, v. 40, n. 10, p. 2244-2251, 2011.

PINTO, A. P.; MARQUES, J. A.; ABRAHÃO, J. J. S.; NASCIMENTO, W. G.; COSTA, M. A. T.; LUGÃO, S. M. B. Comportamento e eficiência ingestiva de tourinhos mestiços confinados com três dietas diferentes. Archivos de Zootecnia, Córdoba, v. 59, n. 227, p. 427-434, 2010.

REGO, F. C. A.; DAMASCENO, J. C.; FUKUMOTO, N. M.; CORTES, C.; HOESHI, L.; MARTINS, E. N.; CECATO, U. Comportamento ingestivo de novilhos mestiços em pastagens tropicais manejadas em diferentes alturas. Revista Brasileira de Zootecnia, Viçosa, MG, v. 35, n. 4, p. 1611-1620, 2006.

SANTANA JÚNIOR, H. A.; SILVA, R. R.; CARVALHO, G. G. P.; CARDOSO, E. O.; MENDES, F. B. L.; PINHEIRO, A. A.; ABREU FILHO, G.; DIAS, D. L. S.; BARROSO, D. S.; SILVA, F. F.; TRINDADE JÚNIOR, G. Comportamento ingestivo de novilhas suplementadas a pasto sob nutrição compensatória. Archivos de Zootecnia, Córdoba, v. 62, n. 237, p. 61-71, 2013.

SANTOS, E. M.; ZANINE, A. M.; PARENTE, H. N.; FERREIRA, D. J.; ALMEIDA J. C. C. Comportamento ingestivo de bezerras (Holandês x Zebu) sob pastejo no cerrado goiano. Ciência Animal Brasileira, Goiânia, v. 7, n. 2, p. 143-151, 2006.

SILVA, R. R.; SILVA, F. F.; PRADO, I. N.; CARVALHO, G. G. P.; FRANCO, I. L.; ALMEIDA, V. S.; CARDOSO, C. P.; RIBEIRO, M. H. S. Comportamento ingestivo de bovinos. Aspectos metodológicos. Archivos de Zootecnia, Córdoba, v. 55, n. 211, p. 293-296, 2006.

TEIXEIRA, F. A.; BONOMO, P.; PIRES, A. J. V.; SILVA, F. F.; MARQUES, J. A.; SANTANA JUNIOR, H. A. Padrões de deslocamento e permanência de bovinos em pastos de Brachiaria decumbens diferidos sob quatro estratégias de adubação. Revista Brasileira de Zootecnia, Viçosa, MG, v. 40, n. 7, p. 1489-1496, 2011. 
TEIXEIRA, F. A.; MARQUES, J. A.; SILVA, F. F.; PIRES, A. J. V. Comportamento ingestivo e padrão de deslocamento de bovinos em pastagens tropicais. Archivos de Zootenia, Córdoba, v. 59, n. 7, p. 57-70, 2010.

VAN SOEST, P. J. Nutritional ecology of the ruminant. $2^{\text {th }}$ ed. Ithaca: Cornell University Press, 1994. 476 p.

ZANINE, A. M.; SANTOS, E. M.; PARENTE, H. N.; FERREIRA, D. J.; CECON, P. R. Hábito de pastejo de vacas lactantes Holandês x Zebu em pastagens de Brachiaria brizantha e Brachiaria decumbens. Arquivo Brasileiro de Medicina Veterinária e Zootecnia, Belo Horizonte, v. 59, n. 1, p. 175-181, 2007.
ZANINE, A. M.; VIEIRA, B. R.; FERREIRA, D. J.; VIEIRA, A. J. M.; LANA, R. P.; CECON, P. R. Comportamento ingestivo de vacas Girolandas em pastejo de Brachiaria brizantha e Coast-cross. Revista Brasileira de Saúde e Produção Animal, Salvador, v. 10, n. 1, p. 85-95, 2009. 
